\title{
STUDI PEMANFAATAN MINYAK JELANTAH SEBAGAI BAHAN BAKU PEMBUATAN BIODIESEL
}

\author{
Studi On The Utilization of Used Oil As Raw Material For Biodiesel
}

\author{
Joni Prasetyo \\ Pusat Teknologi Sumberdaya Energi dan Industri Kimia, BPPT. \\ e-mail: joni.prasetyo@bpt.go.id
}

\begin{abstract}
ABSTRAK
Pemanfaatan minyak jelantah sebagai bahan baku pembuatan biodiesel memberikan beberapa manfaat seperti mengurangi pencemaran lingkungan di began air. Karena masyarakat sekarang ini cenderung membuang minyak jelantah dengan kualitas yang sangat rendah. Selain itu, bahan baku minyak jelantah ini sudah bukan lagi dikategorikan sebagai bahan pangan mengingat bentuknya yang hitam dan encer. Pembuatan biodiesel dengan transesterifikasi suasana basa ini bisa dilakukan dengan biaya yang murah dengan mengggunakan $\mathrm{NaOH}$ teknis yang banyak dijual dipasar dan ethanol teknis. Optimasi dilakukan dengan mempertimbangkan parameter jumlah $\mathrm{NaOH}$ teknis $2 \mathrm{~N}$ mulai dari 10, 25, 40, 55 dan $70 \mathrm{ml}$ dan exces ethanol 0, 25, 50, 75 dan 100\%. Proses transesterifikasi dilakukan pada suhu $80^{\circ} \mathrm{C}$ selama tiga jam dalam pengadukan yang homogen. Kondisi optimum didapatkan dengan menggunakan $10 \mathrm{ml} \mathrm{NaOH} 2 \mathrm{M}$ dan $0 \%$ exces ethanol sebesar $196.64 \mathrm{gr} / 200 \mathrm{gr}$ minyak jelantah. Kondisi ini juga mampu meminimalkan volume glycerol yang hanya berjumlah $79.79 \mathrm{ml}$. Secara keseluruhan FFA biodiesel ini sudah dibawah $0.5 \%$ sesuai dengan yang diharapkan. Adapun kualitas biodiesel melalui pengamatan masa jenis yang menunjukan $0.937 \mathrm{gr} / \mathrm{ml}$ masih harus dilakukan perlakukan lebih lanjut dari target yang diharapkan $0.900 \mathrm{gr} / \mathrm{ml}$, yaitu dengan melakukan penguapan air dalam oven pada suhu lebih tinggi dan durasi yang lebih panjang.
\end{abstract}

Kata kunci: biodiesel, minyak jelantah, transesterifikasi, Fatty Acid Ethyl Ester (FAEE)

\begin{abstract}
Utilization of used cooking oil as a raw material for biodiesel production provides several benefits such as environmental pollution problem in the watershed. Society culture nowadays tends to dispose of the very low quality of used cooking oil to watershed. In addition, this raw materials is no longer categorized as a food ingredient considering its appearance, black and watery shape. Making biodiesel by transesterification in this alkaline condition can be done at low cost using technical $\mathrm{NaOH}$ sold and technical ethanol that are easily available in market. The optimization was conducted at various parameters, $2 \mathrm{~N} \mathrm{NaOH}$ solution amount 10, 25, 40, 55 and $70 \mathrm{ml}$ and excess of ethanol level 0,25,50, 75 and 100\%. The transesterification process was carried out at $80^{\circ} \mathrm{C}$ for three hours with stirring. The optimum condition was obtained by using $10 \mathrm{ml}$ of $\mathrm{NaOH} 2 \mathrm{M}$ and $0 \%$ excess ethanol produced $196.64 \mathrm{gr} / 200 \mathrm{~g}$ of used cooking oil. This condition was also able to minimize the volume of glycerol which was only $79.79 \mathrm{ml}$. Overall, the FFA of biodiesel was less than $0.5 \%$ as expected. The quality of biodiesel was examined through its density at $0.937 \mathrm{gr} / \mathrm{ml}$ but literally the density should be $0.900 \mathrm{~g} / \mathrm{ml}$. In other words, the biodiesel was needed evaporated in the oven at higher temperatures and longer period.
\end{abstract}

Keywords: biodiesel, used cooking oil, transesterifikasi, Fatty Acid Ethyl Ester (FAEE)

\section{PENDAHULUAN}

Sumber energi minyak bumi saat ini mulai menipis seiring meningkatnya pembangunan dan penggunaannya di bidang industri maupun transportasi. Saat ini, banyak negara terutama Indonesia kekurangan bahan bakar minyak (bahan bakar diesel/solar) sehingga perlu 
mengimpor untuk memenuhi kebutuhan dalam jumlah yang besar[1]. Dalam terjadinya peningkatan kebutuhan energi khususnya untuk bahan bakar mesin diesel yang diperkirakan akibat meningkatnya jumlah industri, transportasi dan pusat pembangkit listrik tenaga diesel (PLTD) diberbagai daerah di Indonesia sejak pertengahan tahun 80-an. Hal tersebut dikarenakan stok minyak mentah yang berasal dari fosil terus berkurang seiring dengan meningkatnya jumlah kebutuhan konsumsi.

Dari berbagai macam produk olahan minyak bumi yang digunakan sebagai bahan bakar, maka yang paling banyak pemakaiannya adalah minyak solar. Kebutuhan solar dari tahun ke tahun semakin meningkat, karena solar banyak digunakan sebagai bahan bakar berbagai jenis alat transportasi yang menggunakan mesin diesel (mobil dan kapal laut), bahan bakar berbagai jenis peralatan berat dan pesawat pengangkat (excavator, crane, dll). Bahan bakar berbagai jenis peralatan bengkel dan sebagai bahan bakar penggerak generator pembangkit tenaga listrik.

Selain sifatnya yang tidak dapat terbaharukan penggunaan bahan bakar fosil menyebabkan berbagai permasalahan lingkungan. Dewasa ini kepedulian terhadap lingkungan hidup yang semakin tinggi, dipicu oleh semakin memburuknya kondisi bumi yang kita tempati. Pemanasan global akibat efek rumah kaca mengancam kehidupan manusia karena dapat menyebabkan naiknya permukaan airlaut dari melelehnya es di kutub.polusi yang membahayakan bagi lingkungan, terutama di kota-kota besar yang penuh dengan polusi asap kendaraan dan industri. Dan penggunaan BBM sebagai bahan bakar utama ikut memberi andil dalam kerusakan lingkungan yang terjadi. Emisi gas buang hasil pembakaran bahan bakar mengandung

Tabel 1 Emisi Minyak Bensin dan Minyak

Solar

\begin{tabular}{lcc}
\hline \multicolumn{1}{c}{ Emisi } & Bensin & Diesel \\
\hline Hidrokarbon & 15.8 & 2.6 \\
Karbon & 24.4 & 5.4 \\
Dioksida & & \\
Nitrogen & 19.9 & 5.2 \\
Oksida & 3.2 & 3.2 \\
Sulfur Oksida & 2 & 1.9 \\
Partikulat & 0.4 & 0 \\
Timbal & & \\
\hline
\end{tabular}

Sumber: The World Bank

senyawa-senyawa yang membahayakan bagi kesehatan.

Pada tabel 1 dapat dilihat emisi dari minyak bensin dan minyak solar dalam gram/liter.

Usaha untuk mengadakan diversifikasi sumber energi sudah banyak dilakukan, mulai dari penggunaan bahan bakar gas sampai dengan pengembangan teknologi mesin bertenaga matahari. Namun pengaplikasian bahan bakar pada mesin kendaraan membutuhkan modifikasi dan penambahan infrastruktur, demikian juga dengan tenaga matahari. Agar dapat bersifat aplikatif maka alternatif bahan bakar harus dalam bentuk cair. Selain itu bahan bakar alternatif sebaiknya bersifat dapat diperbaharui dan juga ramah lingkungan.

Serangkaian penelitian telah dilakukan diprogram studi teknik mesin Universitas Udayana terkait dengan upaya untuk membuat bahan bakar pengganti minyak solar. Tahun 1994 penelitian dimulai dengan jalan mencampur minyak nabati ke dalam minyak solar, penelitian selanjutnya adalah dengan jalan melakukan pemanasan pada minyak nabati sebagai minyak solar, hingga akhirnya pengolahan minyak nabati menjadi 
biodiesel ini dibuat dengan menggunakan minyak nabati dari jenis minyak kelapa sawit yang dicampur dengan alkohol dan katalis.

Pengembangan biodiesel merupakan alternatif yang potensial untuk mengatasi permasalahan keterbatasan sumber bahan bakar fosil, karena berasal dari bahan-bahan yang dapat diperbaharui. Selain itu penggunaan biodiesel dapat mengurangi emisi pada hasil pembakaran, sehinggan lebih bersifat ramah lingkungan. Indonesia sangat potensial dalam pengembangan biodiesel karena merupakan negara produsen minyak kelapa sawit terbesar kedua di dunia, sehingga suplai bahan baku dalam pembuatan biodiesel sudah tersedia.

Biodiesel merupakan salah satu potensial permasalahan energi yang dapat dimanfaatkan sebagai pengganti bahan bakar solar/diesel. Minyak biodiesel merupakan bahan bakar alternatif yang terbuat dari sumber daya alam yang dapat diperbarui, diantaranya adalah minyak tumbuhan dan hewan. Biodiesel ini dapat dijadikan sebagai bahan bakar pengganti solar, sebab komposisi fisika-kimia antara biodiesel dan solar tidak jauh berbeda. Pembakaran bahan bakar fosil menghasilkan salah satu polutan yaitu sulfur dioksida (SO2) dan mengakibatkan polusi udara meningkat. Selain sebagai energi yang terbarukan, biodiesel memiliki beberapa keunggulan dibandingkan dengan bahan bakar yang ramah lingkungan karena menghasilkan emisi yang jauh lebih baik (bebas sulfur, smoke number rendah) sesuia dengan isu-isu global [2], asap buangan biodiesel tidak hitam dan asap buangnya berkurang 75\% dibandingkan solar biasa. Sifat biodegradable juga baik, karena lebih dari $90 \%$ biodiesel dapat terurai dalam 21 hari $[3,4]$.
Bahan baku yang bisa dapat menghasilkan minyak biodiesel seperti, minyak nyamplung, kelapa sawit, kelapa, atau minyak nabati lainnya. Penggunaan minyak kelapa sawit (Crude Palm Oil) terbesar adalah sebagai bahan baku minyak goreng. Minyak goreng merupakan salah satu kebutuhan bahan pokok penduduk Indonesia dengan tingkat konsumsi yang mencapai lebih dari 2,5 juta ton pertahun, atau lebih dari 12 kg/orang/tahun. Minyak goreng yang paling banyak di gunakan di Indonesia adalah yang berbahan baku minyak kelapa sawit (lebih dari 70\%). Penggunaan minyak goreng kelapa sawit sebagai biodiesel secara teknis lebih menguntungkan karena sudah melalui berbagai proses penghilangan impuritis, kandungan asam lemak dan lemak padat. Namun secara ekonomis penggunaan minyak goreng kelapa sawit sebagai bahan baku pembuatan biodiesel secara teknis tidak menguntungkan. Hal ini disebabkan oleh kebijakan harga BBM di Indonesia relatif rendah, sehingga jika dibandingkan dengan harga minyak goreng kelapa sawit terdapat perbedaan yang relatif besar [5].

Khususnya minyak kelapa sawit dan minyak kelapa pada saat ini banyak dimanfaatkan sebagai bahan pangan[6]. Oleh karena itu pemakaian minyak kelapa sawit dan minyak kelapa ini dihindari karena bisa berakibat kompetisi dengan bahan pangan. Adapun pemanfaatan minyak nyamplung masih mempunyai kendala ketersediaan bahan bakunya. Kontinuitas minyak nabati dari nyamplung pada saat ini masih sangat sulit walaupun minyak nyamplung ini cocok untuk digunakan sebagai bahan baku pembuatan biodiesel karena tidak akan mengakibatkan kompetisi dengan bahan pangan. Sebagai jalan yang bisa mendukung kontinuitas produksi dan tidak berkompetisi dengan bahan pangan, maka digunakan 
minyak goreng bekas atau minyak jelantah [7] dengan kualitas yang paling redah. Minyak jelantah merupakan salah satu bahan baku yang memiliki peluang untuk pembuatan biodiesel [8-10]. Penggunaan minyak goreng bekas atau minyak jelantah sebagai bahan baku biodiesel, karena secara karakteristik masih ada kesamaan dengan minyak kelapa sawit: masih mengandung trigliserida, di samping asam lemak bebas. Secara ekonomi, minyak goreng bekas yang kualitas sangat rendah seperti bentuknya yang sudah hitam, saat ini dapat diperoleh secara gratis karena merupakan limbah yang sudah tidak digunakan lagi. Data statistik menunjukkan bahwa terdapat kecenderungan peningkatan produksi minyak goreng. Selain ketersediaannya yang relatif berlimpah, minyak jelantah merupakan limbah sehingga berpotensi mencemari lingkungan berupa naiknya kadar COD (Chemical Oxygen Demand) dan BOD (Biology Oxygen Demand) dalam perairan, selain itu jugamenimbulkan bau busuk akibat degradasi biologi.

Pada penelitian ini, pengolahan minyak jelantah mengubah molekul-molekul asam lemak tak jenuh dalam minyak nabati menjadi asam lemak jenuh dengan menggunakan alkohol (methanol \& etanol) dan katalis $\mathrm{NaOH}$ teknis pada proses transesterifikasi [9,10]. Campuran dari minyak jelantah dengan $\mathrm{NaOH}$ teknis akan membentuk gliserol yang mengendap dibagian bawah dan etil ester (biodiesel) mengapung dipermukaan. Berdasarkan penelitian tersebut maka terbuka kesempatan untuk membuat biodiesel sebagai pengganti bahan bakar solar. Dengan menggunakan minyak jelantah atau minyak goreng bekas.

\section{BAHAN DAN METODE}

\section{Bahan}

Minyak jelantah. Minyak jelantah yang digunakan disini merupakan minyak goreng dengan kualitas sangat rendah yang berwarna hitam dan encer. Minyak goreng semacam ini didapatkan dari penjual dipinggir jalan seperti ayam goreng atau lele goreng maupun penjual gorengan.

NaOH teknis. Katalis $\mathrm{NaOH}$ yang digunakan bias didapatkan dari took bahan kimia yang umumnya ada dipasaran. $\mathrm{NaOH}$ teknis atau biasa disebut caustic soda ini banyak digunakan untuk pembuatan sabun, mengandung beberapa logam sehingga bahan ini tidak bisa digunakan untuk pemrosesan makanan. Pemakaian $\mathrm{NaOH}$ teknis ini juga lebih didasarkan pada pertimbangan ekonomi, harganya murah.

Ethanol. Pemilihan ethanol teknis sebagai reaktan lebih didasarkan kemudahan didapatkan di pasaran dibandingkan dengan methanol yang saat ini lebih banyak digunakan sebagai reaktan pada pembuatan biodiesel di industry. Keuntungan lainnya adalah ethanol lebih tidak mudah menguap dibandingkan methanol. Titik didih ethanol adalah $78.37^{\circ} \mathrm{C}$ sedangkan methanol $64.7^{\circ} \mathrm{C}$ [12].

\section{Metode}

Pembuatan biodiesel dari minyak goreng bekas dilakukan dalam 3 tahap:

Tahap Persiapan. Minyak jelantah yang didapatkan dari berbagai sumber dijadikan satu dalam satu wadah, diaduk hingga merata (homogen). Minyak jelantah ini disaring menggunakan saringan yang atasnya dilapisi dengan tisu. Pada tahapan ini kotoran padatan akan tersaring dan akan langsung diproses dalam kondisi basa, transesterifikasi.

Proses pembuatan biodiesel. Pembuatan biodiesel ini dilakukan dalam suasana basa 
dengan menggunakan katalis cair yang akan bereaksi secara homogen dengan minyak jelantah yang sudah disaring. Adapun katalis $\mathrm{NaOH}$ cair disiapkan dalam konsentrasi 2M. $\mathrm{NaOH}$ ini dicampur lebih dahulu dengan ethanol dalam erlenmeyer berpengaduk. Jumlah ethanol dan $\mathrm{NaOH}$ dalam studi ini merupakan parameter yang digunakan untuk optimasi pembuatan biodiesel. Optimasi ini dilakukan dengan mengatur jumlah excess pemakaian ethanol sebagai reaktan: 0 , 25, 50, 75 dan 100\% terhadap kebutuhan reaksi minyak jelantah teoritis. Optimasi kedua pada studi ini dilakukan untuk meminimalkan jumlah $\mathrm{NaOH} 2 \mathrm{M}$ yang digunakan, dimulai dari penggunaan 10, 25, 40, 55, dan $70 \mathrm{ml}$ [13-15].

Proses esterifikasi dilakukan dengan basis jumlah minyak jelantah $200 \mathrm{ml}$ ke dalam beaker glass. Minyak jelantah tersebut dipanaskan menggunakan hot plate pada suhu $60^{\circ} \mathrm{C}$ yang disertai pengadukan dengan magnetic stirer. Selanjutnya volume katalis $\mathrm{NaOH}$ sebanyak $50 \mathrm{ml}$ dan ethanol sebanyak $100 \mathrm{ml}$ kedalam campuran tersebut sedikit demi sedikit sehingga campuran tersebut homogen. Setelah pengadukan tersebut, pra crude methyl ester diendapkan selama 1 hari kemudian disaring lagi dengan tisu. Pada akhir proses esterifikasi ini akan terbentuk gliserol yang larut dalam air sehingga bisa dipisahkan dari biodiesel dengan menggunakan corong pemisah.

Proses pemurnian biodiesel. Pemurnian biodiesel diawali dengan proses pencucian sisa $\mathrm{NaOH}$ yang masih terlarut dalam biodiesel. Proses pencucian ini dilakukan dengan menambahkan aquadest sebanyak $100 \mathrm{ml}$. Menuangkan air pencuci (aquades) kedalam crude methyl ester yang akan dicuci, dilakukan pengadukan dan didiamkan sehingga terjadi pemisahan antara methyl ester dan air. Pemurnian terakhir dilakukan untuk memisah kandungan air yang tersisa dalam biodiesel. Pemurnian biodiesel dari aquadest tersisa dilakukan melalui pemanasan biodiesel dalam oven pada suhu $70-80^{\circ} \mathrm{C}$ selama kurang lebih 12 jam.

\section{Analisa}

Beberapa parameter yang dianalisa dalam studi ini dilakukan untuk menghitung:

Kadar FFA. Sebanyak 5 gram biodiesel yang telah ditentukan massa jenisnya pada suhu ruang, dipipet menggunakan pipet volume, dimasukkan kedalam erlenmeyer $250 \mathrm{ml}$ dan ditambahkan ethanol 95\% sebanyak 50ml. Larutan ditambahkan $1 \mathrm{ml}$ (20 tetes) indikator fenolftalein (PP). Larutan tersebut kemudian dititrasi dengan larutan standar $\mathrm{NaOH}$ hinggaberwarna merah muda konstan (tidak berubah selama 15 detik) $[16,17]$. Jumlah $\mathrm{NaOH}$ yang digunakan untuk titrasi dicatat untuk menghitung bilangan asam. Pengerjaan ini dilakukan sebanyak tiga kali. Perhitungan:

Kadar FFA =

$\mathrm{V} \times \mathrm{N} \times \mathrm{BM}$ asam palmitat $\mathrm{x} 100 \%$

\section{G x 1000}

Dimana:

$\mathrm{V}=$ Jumlah volume $\mathrm{NaOH}$ untuk titrasi (ml)

$\mathrm{N}=$ Normalitas

$\mathrm{G}=$ massa biodiesel (g)

Kuantitas konsentrasi gliserin (glycerol). Penentuan lipida atau lemak dalam suatu bahan dapat dilakukan dengan menganalisa uji bilangan iodin. Bilangan iodine adalah gram iodine yang diserap oleh 100 gram lemak, akan mengadisi ikatan asam lemak tidak jenuh bebas maupun dalam bentuk ester. Bilangan iodine tergantung pada jumlah asam lemak tidak jenuh dalam lemak. Lemak yang akan diperiksa dilarutkan dalam kloroform $\left(\mathrm{CHCl}_{3}\right)$ kemudian ditambahkan larutan iodine berlebihan ( 0,1-0,5 gram.) sisa 
iodine yang tidak bereaksi dititrasi dengan tiosulfat.

Berat jenis atau Densitas. Perhitungan densitas dilakukan dengan menggunakan alat piknometer. Piknometer disiapkan dengan terlebih dahulu dikeringkan dengan dimasukan ke oven dengan suhu $60^{\circ} \mathrm{C}$ selama 15 menit. Piknometer kosong ditimbang. Selanjutnya biodiesel dimasukan kedalam piknometer tersebut dan ditimbang lagi. Perhitungan berat jenis biodiesel adalah sebagai berikut:

Masa minyak $\left(\frac{\mathrm{gr}^{\mathrm{m}}}{\mathrm{ml}}\right)=$
$\frac{\text { (massa minyak tpicno)-massa picno }}{\text { volume picno }}$

\section{HASIL DAN PEMBAHASAN}

Minyak jelantah sebagaimana minyak goreng dari kelapa sawit mempunya kandungan yang hamper sama, trigliserida dari asam jenuh dengan rantai panjang mempunyai titik leleh yang lebih tinggi daripada yang terbuat dari asam jenuh dengan rantai pendek atau tak jenuh. Dengan transesterifikasi, kandungan asam lemak bebas dapat diminimalisir hingga $2 \%$ dan diperoleh tambahan ester [18]. Parameter utama dalam hasil reaksi transesterifikasi adalah rasio molar antara trigliserida dan alkohol dalam studi ini digunakan ethanol. Faktor lain yang mempengaruhi kandungan ester pada biodiesel, diantaranya kandungan gliserol, jenis alkohol yang digunakan pada reaksi transesterifikasi, jumlah katalis sisa $[18,19]$.

Pembentukan FAEE dari minyak jelantah dan ethanol pada kondisi basa (dengan katalis $\mathrm{NaOH}$ ) menghasilkan produk biodiesel dan produk samping gliserin. Gliserin (glycerol) merupakan suatu tribasic alcohol yang terdapat di alam dalam bentuk Trigliserida + Alkohol $\rightarrow$ Gliserin + FAEE

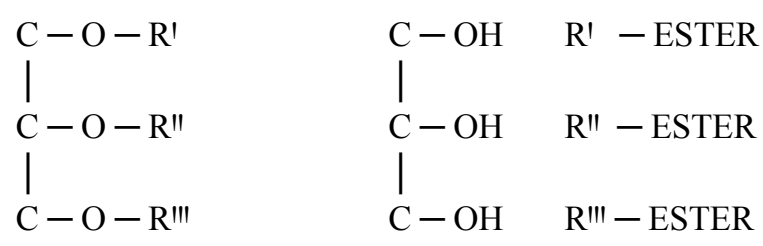

Gambar 1. Proses Transesterifikasi Minyak Jelantah

trigliserida yang merupakan trigliseril ester dari asam lemak. Gliserin mengandung gugus alkohol primer dan alkohol sekunder yang dapat mengalami reaksi oksidasi. Sebagai hasil samping pengolahan minyak jelantah, gliserol memiliki potensi untuk dimanfaatkan. Namun, pemurnian limbah gliserol menjadi gliserol murni sangat mahal dan tidak efektif.

Rendemen dari hasil penelitian ini, dapat dilihat memiliki pola dari segi berat minyak biodiesel, berat gliserol, pengecekan FFA (Free Fatty Acid), dan massa jenis biodiesel (densitas). Dengan beberapa variabel, dapat ditemukan kondisi optimum dari biodiesel tersebut.

\section{Biodiesel}

Biodiesel yang didapatkan dari Dari pembuatan biodiesel ini dapat diperoleh hasil data seperti pada Gambar 2. Gambar 2 menunjukan berat biodiesel yang dihasilkan dari minyak jelantah $200 \mathrm{ml}$. Kondisi optimum yang didapatkan pada setiap pemakaian jumlah $\mathrm{NaOH}$ adalah berbedabeda untuk masing-masing excess pemakaian ethanol. Pada penggunaan $\mathrm{NaOH} 10,25,40$ dan $55 \mathrm{ml}$ didapat hasil biodiesel tertinggi dengan excess ethanol 0\% dengan urutan 196,64; 196.52; 187.62 dan 182.28 gram. Adapun pemakaian $70 \mathrm{ml} \mathrm{NaOH}$ optimal pada excess ethanol 50\% sebesar 195.82 gram. Produk hasil berat biodiesel kemungkinan dipengaruhi dengan banyaknya 


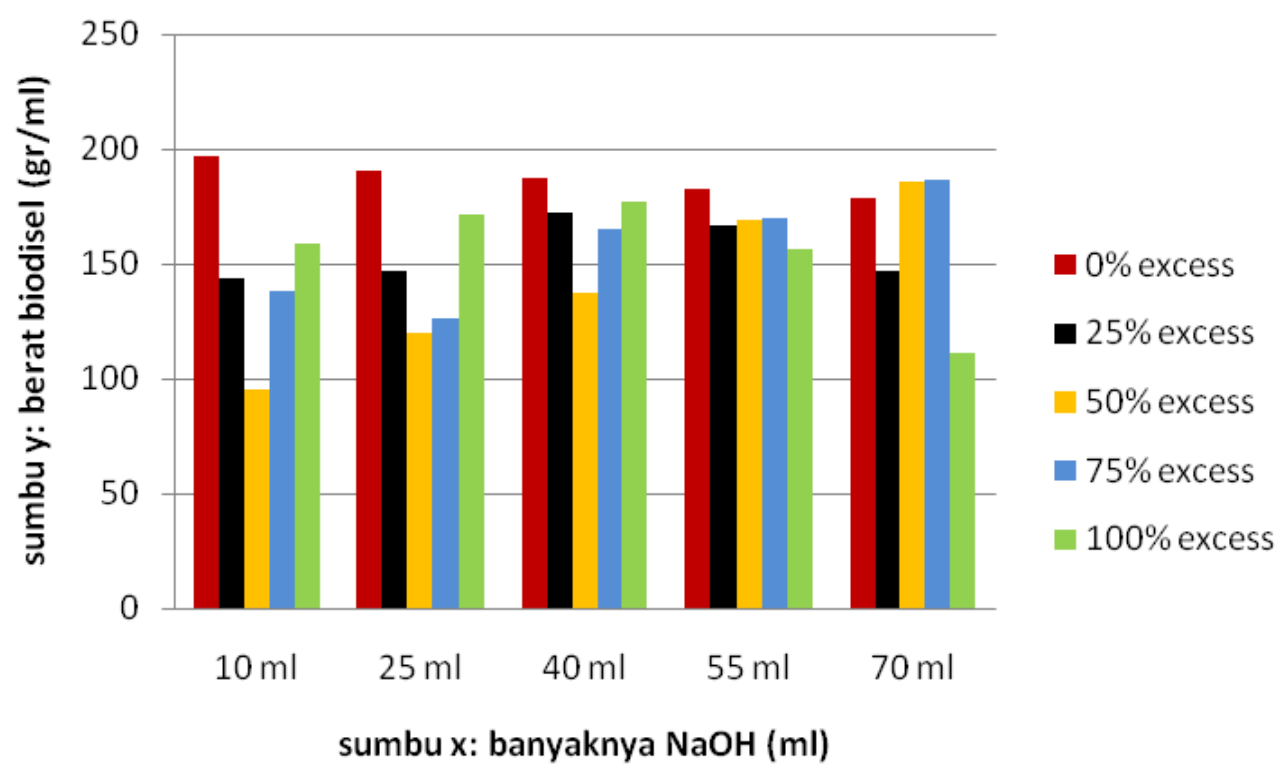

Gambar 2. Berat biodiesel yang dihasilkan

jumlah air yang digunakan untuk pelarut $\mathrm{NaOH}$ dimana semakin besar jumlah $\mathrm{NaOH}$ berarti semakin besar pula jumlah air yang ada. Besarnya jubiodiesel pada excess $0 \%$ menunjukan bahwa perhitungan teoritis kebutuhan ethanol sebagai reaktan sudah cukup untuk mereaksikan menjadi biodiesel. Dengan kata lain, penambahan jumlah ethanol tidak akan menambah hasil biodiesel yang merupakan produk target pada studi ini. Adapun pemakaian $\mathrm{NaOH} 2 \mathrm{M}$ sebanyak 70 $\mathrm{ml}$ menunjukan bahwa hasil maksimal pada excess ethanl 50\%. Hal ini berkaitan dengan sabun yang terbentuk padat sehingga mudah dipisahkan terhadap glycerol dan biodiesel. Ternyata hal ini efektif meningkatkan produk biodiesel.

\section{Gliserin}

Gliserin (glycerol) merupakan produk samping. Karena pemanfaatan glycerol ini memerlukan proses pemurnian yang mahal. Maka pada studi ini diharapkan produk glycerol yang seminimal mungkin. Hasil yang diperoleh pada studi ini sebagaimana ditunjukan pada gambar 3. Besarnya glycerol dalam pembuatan FAEE ini sangat berkaitan dengan jumlah air yang digunakan baik pada larutan $\mathrm{NaOH} 2 \mathrm{M}$ maupun semakin besarnya excess ethanol yang digunakan. Oleh karena itu, jumlah minimal glycerol ini didapatkan pada penggunaan $10 \mathrm{ml} \mathrm{NaOH} 2 \mathrm{M}$ dan excess ethanol $0 \%$ yaitu $79.79 \mathrm{ml}$. Secara umum, glycerol ini akan semakin besar volumenya dengan semakin besarnya volume $\mathrm{NaOH} 2 \mathrm{M}$ yang digunakan dan semakin besarnya excess ethanol yang digunakan dimana volume glycerol terbanyak didapatkan pada $70 \mathrm{ml} \mathrm{NaOH} 2 \mathrm{M}$ dan $100 \%$ excess ethanol yaitu $303.35 \mathrm{ml}$, suatu perbedaan yang significant. Jadi pada studi disarankan untuk meminimalkan jumlah ethanol dan $\mathrm{NaOH}$ 2M. Dalam penentuan SNI 7182:2015 gliserol bebas maksimal 0,24\%-massa.

\section{Massa jenis atau densitas}

Pengukuran massa jenis ini diperlukan untuk memprediksi kandungan air dalam biodiesel. Densitas air mendekati $1 \mathrm{~g} / \mathrm{cm}^{3}$ adapun densitas biodiesel berkisar 0,860$0,900 \mathrm{~g} / \mathrm{cm}^{3}$. Oleh karena itu, diharapkan berat jenis biodiesel yang dihasilkan disini 


\section{Prasetyo}

diharapkan mendekati masa jenis biodiesel teoritis. Gambar 4 menunjukan bahwa masa

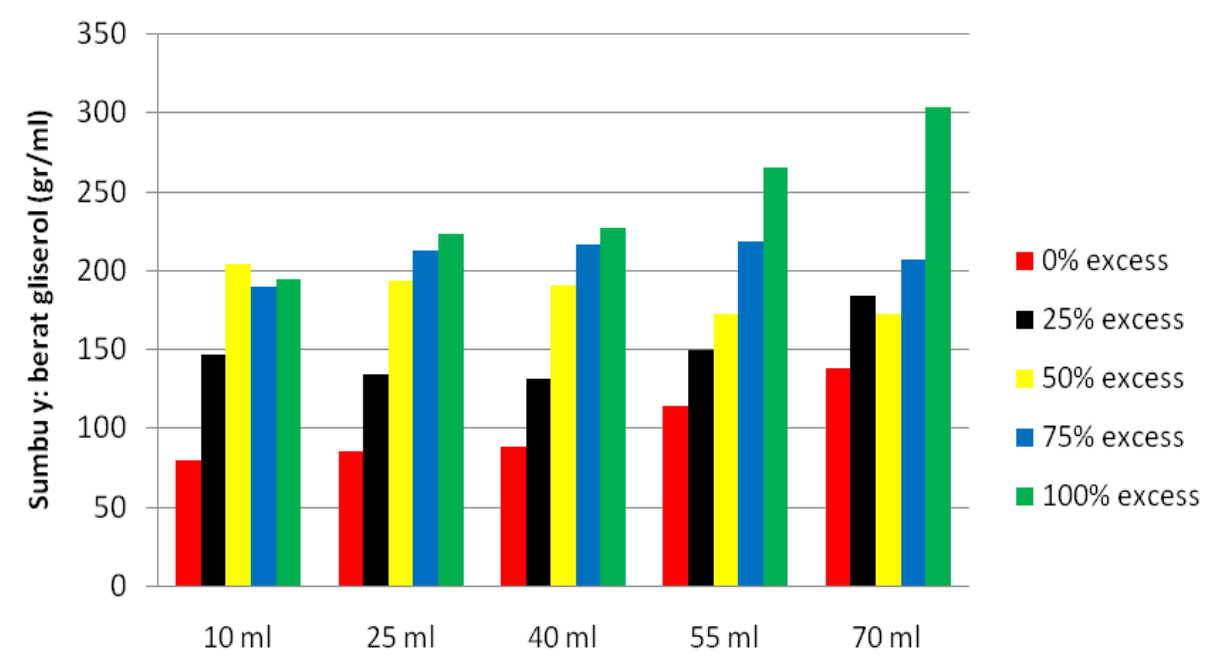

Sumbu x: banyaknya $\mathrm{NaOH}(\mathrm{ml})$

Grafik 3 Hasil berat gliserol

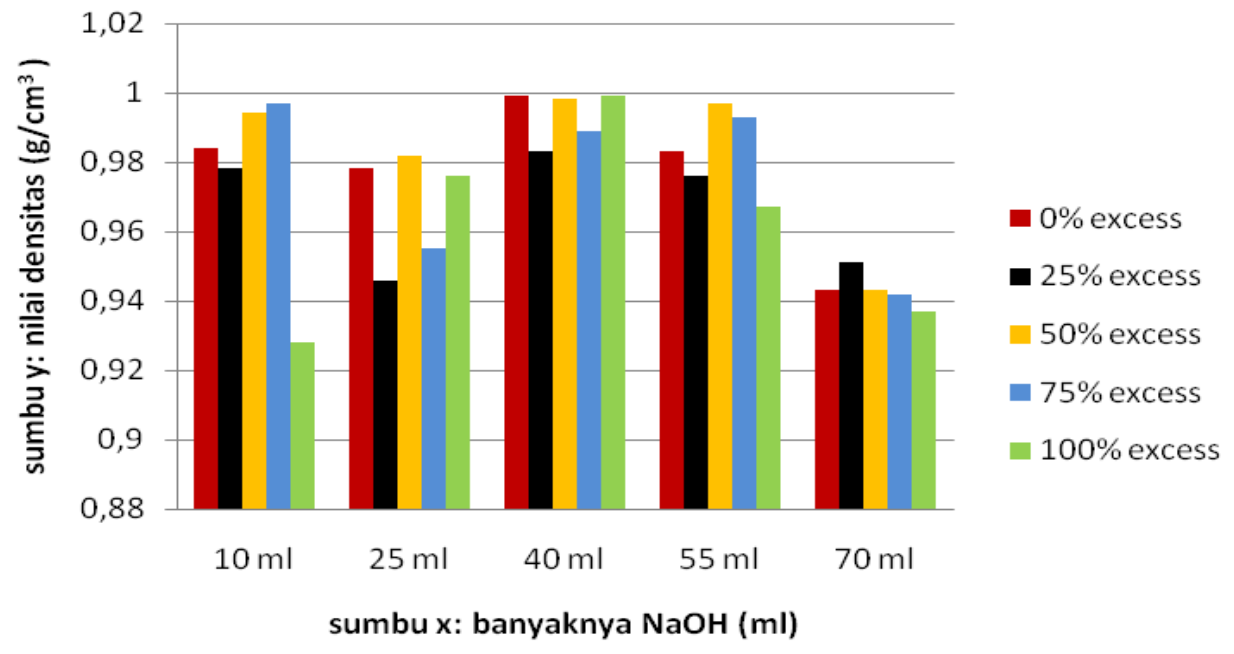

Grafik 4 Berat jenis biodiesel.

jenis biodiesel yang paling mendekati masa jenis biodiesel teoritis adalah pada penggunakan $70 \mathrm{ml} \mathrm{NaOH} 2 \mathrm{M}$ dan $100 \%$ excess ethanol yang berkisar antara 0.937 sampai 0,95 gr/ml. Hasil ini menunjukan kemungkinan masih adanya kandungan air pada biodieseltersebut.

\section{Massa jenis atau densitas}

Pengukuran massa jenis ini diperlukan untuk memprediksi kandungan air dalam biodiesel. Densitas air mendekati $1 \mathrm{~g} / \mathrm{cm}^{3}$ adapun densitas biodiesel berkisar 0,860$0,900 \mathrm{~g} / \mathrm{cm}^{3}$. Oleh karena itu, diharapkan berat jenis biodiesel yang dihasilkan disini diharapkan mendekati masa jenis biodiesel teoritis. Gambar 4 menunjukan bahwa masa jenis biodiesel yang paling mendekati masa jenis biodiesel teoritis adalah pada penggunakan $70 \mathrm{ml} \mathrm{NaOH} 2 \mathrm{M}$ dan $100 \%$ excess ethanol yang berkisar antara 0.937 sampai 0,95 gr/ml. Hasil ini menunjukan 
kemungkinan masih adanya kandungan air.

\section{FFA (Free Fatty Acid)}

FFA (Free Fatty Acid) atau asam lemak jenuh merupakan produk yang dihasilkan ketika suatu trigliserida mengalami reaksi hidrolisis. Pada umumnya disyaratkan FFA ini nilainya dibawah 0.5\%. Pada pengukuran FFA ini semua sample adalah dibawah 0.5\%. Pengukuran FFA dengan metode titrasi yang menggunakan indicator pH PP ini harus dilaksanakan dengan teliti dan standard warna yang sama. Sebaiknya dilakukan oleh orang sama untuk membndingkan hasil yang konsisten. Pada pengukuran FFA oleh orang yang berbeda seringkali menghasilkan data yang berbeda secara cukup signifikan.

\section{KESIMPULAN}

Studi pembuatan biodiesel dari minyak jelantah ini menunjukan potensi pemanfaatan minyak jelantah sebagai bahan bakar melalui system sumbu dengan nyala api (gambar tidak ditunjukan).

Pembuatan biodiesel ini sebaiknya dilakukan dengan meminimalkan jumlah kandungan air yang digunakan melalui minimalisasi volume larutan katalis $\mathrm{NaOH}$ dan excess ethanol yang digunakan. Oleh karena itu, hasil maksimum biodiesel pada studi ini dicapai pada penggunakaan $10 \mathrm{ml}$ $\mathrm{NaOH} 2 \mathrm{M}$ dan excess ethanol $0 \%$ teoritis yang mencapai $196.64 \mathrm{ml}$. Selain itu, minimalisasi air yang digunakan tersebut, juga akan meminimalkan volume glycerol, produk samping, yag dihasilkan. Volume glycerol diharapkan seminimalkan mungkin karena untuk pemanfaatan lebih lanjut memerlukan biaya yang tinggi. Pada studi ini, volume minimal glycerol juga pada penggunakaan $10 \mathrm{ml} \mathrm{NaOH} \mathrm{2M}$ dan excess ethanol 0\%, yaitu $79.79 \mathrm{ml}$. pada biodiesel tersebut.

Kualitas biodiesel yang dilihat dari masa jenis teoritis dari literatur ternyata menunjukan bahwa masih terlalu tinggi yaitu $0.937 \mathrm{gr} / \mathrm{ml}$ dari yang diharapkan 0.900 $\mathrm{gr} / \mathrm{ml}$. Kendala ini bias diantisipasi dengan pemanasan dioven dengan suhu yang lebih tinggi dan waktu yang lebih lama.

\section{DAFTAR PUSTAKA}

[1] Agus Sugiyono, Anindhita, Laode M.A. Wahid, and Adiarso, Outlook Energi Indonesia.: Badan Pengkajian dan Penerapan Teknologi, 2016.

[2] Basha, Syed Ameer \& Gopal, K. Raja \& Jebaraj, S., 2009. "A review on biodiesel production, combustion, emissions and performance," Renewable and Sustainable Energy Reviews, Elsevier, vol. 13(6-7), pages 1628-1634, August.

[3] Mudge SM, Pereira G, 1999. Stimulating the biodegradable of crud oil with biodiesel preliminary result. Spill Science \& Technology Bulletin 5: 353-355.

[4] Speidel HK, Lightner RL dan Ahmed I, 2000, "Biodegradability of New Engineered Fuels Compared to Conventional Petroleum Fuels and Alternative Fuels in Current Use", Twenty-First Symposium on Biotechnology for Fuels and Chemicals pp 879-89, Part of the Applied Biochemistry and Biotechnology book series (ABAB). DOI 10.1007/978-1-4612-1392-5_69

[5] Swern.1964. Bailey's Industrial Oil and Fast Product, pp.948-951: Interscience Publisher Inc. New York.

[6] Harrington KJ. 1986. Chemical and physical properties of vegetable oil 
ester and their effect on diesel fuel perfomance. Biomass 9(1): 1-17.

[7] Ardra. 2015. "Pengolahan Minyak Goreng Bekas Menjadi Biodiesel” $<$ https://ardra.biz/sain-teknologi/ilmudan-teknologi-terapan/pengolahanminyak-goreng bekas-menjadibiodiesel/> Diakses pada 11 Mei 2017

[8] Farid, Salman dan Juhansyah, Mohamad. 2005. "Pembuatan biodiesel dari minyak jelantah”. Laporan Penelitian: Jurusan Teknik Kimia, Fakultas Teknologi Industri, Institut Teknologi Indonesia, Serpong.

[9] Sholikhah MD, Paryanto I, Barus BR, 2009, "Efek Kualitas Minyak Jelantah Terhadap Harga Proses Produksi dan Kualitas Biodiesel”, Seminar Nasional Teknik Kimia Indonesia - SNTKI, Bandung.

[10] Rahkadima,Y,T. \& Abdi,P. 2016. Produksi Biodiesel Dari Minyak Goreng bekas Menggunakan Katalis Kalsium Oksida: Program Studi Teknik Kimia,Fakultas Teknik,Universitas NU Sidoarjo. Indonesian: Journal of Research and Technologies 2.

[11] Polsri. 2013. "Eprints, Minyak Jelantah"

$<$ http://eprints.polsri.ac.id/94/3/BAB\%

20II.pdf $>$ Diakses pada 15 Nopember 2017

[12] Jun-feng Wang,' Xue-mei Li, Hong Meng, Chun-xi Li, Zi-hao Wang, 2009, "Boiling temperature measurement for water, methanol, ethanol and their binary mixtures in the presence of a hydrochloric or acetic salt of mono-, di- or tri-ethanolamine at $101.3 \mathrm{kPa}$,
The Journal of Chemical Thermodynamics, Volume 41, Issue 2, February 2009, Pages 167-170. doi.org/10.1016/j.jct.2008.10.001

[13] Ahlsy. 2015. "Parameter Dasar Analisa Minyak dan Lemak" $<$ http://ahlsy.blogspot.co.id/2015/07/pa rameter-dasar-analisa-minyak-danlemak.html> Diakses pada 13 Nopember 2017

[14] Freedman, B.E.H and T.L.Mounts. 1984. Variabel Affecting th Yield of Fatty Esters from Transesterified Vegetable Oils: J. Am. Oil Chem. Soc, 61, pp.1638-1643. New York.

[15] Gerpen, J.V., 2005, Biodiesel Processing and Production, Fuel Processing Technology, Elsevier

[16] Kirk, R.E and Othmer, D.F. 1951. Encyclopedia of Chemical Technology, vol.5, pp. 781-790: Interscience Incyclopedia Inc. New York.

[17] NMS Sanjiwani, Suaniti, dan Ni Luh Rustini, 2015. "Bilangan peroksida, bilangan asam, dan kadar FFA biodiesel dengan penambahan antioksidan dari kulit buah pisang kepok (Musa paradisiaca Linn.)”. Jurnal Kimia, Vol. 02, No. 259-266

[18] Ramadhas, dkk. 2005. Pembuatan Biodiesel dari Minyak Sawit dengan Esterifikasi Dua Tahap: Laporan Penelitian, Laboratorium Prose Kimia, Jurusan Teknik Kimia, Universitas Gadjah Mada. Yogyakarta.

[19] Fessenden, R.J and Fessenden, J.S. 1979. Kimia Organik, Jilid I. Jakarta: PT.Erlangga 